\title{
TEACHERS ISSUES AND CONCERNS ON THE USE OF MODULAR LEARNING MODALITY
}

\author{
Tarhata S. Guiamalon ${ }^{1 *}$, Sittie Almirah S. Alon ${ }^{2}$ and Sofia U. Camsa ${ }^{3}$ \\ ${ }^{1}$ Assoc.Prof. Dr., Cotabato State University, Philippines, \\ tarhataguiamalon@yahoo.com \\ ${ }^{2}$ Teacher 1, Maslabeng Elementary School, Buluan District Maguinadano I Division, BARMM \\ ${ }^{3}$ Teacher III, Datu Nakan Memorial Elementary School, Bagumbayan, \\ Sultan Kudarat Division, Region XII \\ ${ }^{*}$ Corresponding Author
}

\begin{abstract}
To consider the learners in rural areas where the internet is inaccessible for online learning, the Modular Learning modality is currently used by all public schools in the Philippines. Modular earning is a form of distance learning that uses Self-Learning Modules (SLM) and is highly convenient for most typical Filipino students. It was also the most preferred learning system of the majority of parents/guardians for their children. The SLM is based on the most essential learning competencies (MELCS) provided by the Department of Education. The study was conducted to determine the issues and concerns about the use of Modular Distance Learning Modality among teachers. Of the ten different public elementary schools within the district of Buluan, Division of Maguindanao I, It found out that teachers are well-oriented and prepared to perform their tasks and functions on modular distance learning education in times of pandemic. They also have enough training and skill development necessary to effectively and efficiently do their job. Parents/guardians can able to support their children in the new learning modality, but some of them are hampered because of the incapability of facilitating and explaining the modules provided for their children. The study shows that the elementary schools have given sufficient funds and resources and are utilized in their proper allocation. These schools were located at Buluan where strategically located in the southern tip of the Maguindanao Province in the Bangsamoro Autonomous Region in Muslim Mindanao (BARMM). It is composed of seven Barangays occupying a total land area of 69,950 hectares. It has a substantial share of the famous Buluan Lake.
\end{abstract}

Keywords: Modular Distance Learning, Learning Modality, Teachers Issues and Concerns

\section{INTRODUCTION}

The COVID-19 pandemic is definitely a health issue. Schools are closed globally. The country and the entire world are facing new challenges brought about by an unforeseen public health crisis. There is no doubt that, like many other aspects of daily life, COVID19 has had a significant impact on students, teachers, and educational organizations around the world.(Mailizar, Almanthari, Maulina, and Bruce, 2020). 
This epidemic creates barriers to face-to-face and even blended learning; however, the education sector needs to rethink and regulate the use of technology in such a way that distance learning can be carried out between students and teachers in emergency situations. Hence, whether or not negative or positive results of emergency remote teaching, the educational systems worldwide are left with no choice but to understand, experience, and accept the great and rapid changes (Hung, Chou, Chen \& Own, 2010) in adopting the concepts of emergency remote education (Bozkurt \& Sharma, 2020).

In response to this crisis and to ensure the continuity of learning while assuring the health, safety, and wellbeing of all learners, teachers, and other employees, the Department of Education instituted DepEd Order No.12 series of 2020 to establish new learning delivery modalities in all levels embodied in the Learning Continuity Plan (LCP) for the school year 2020-2021.

The alternative modes of delivering learning were envisioned to reach all learners regardless of who and where they are. Among these implemented learning delivery modalities (LDMs) were Distance Learning, Blended Learning, and Home-schooling. The Department of Education (DepEd) conducted Learning Enrolment and Survey Form (LESF) on school opening (Department of Education, 2020), it was found out that Modular learning, a form of distance learning that uses Self-Learning Modules (SLM) is one of the highly convenient for most of the typical Filipino students. It was also the most preferred learning system of the majority of parents/guardians for their children. The SLM is based on the most essential learning competencies (MELCS) provided by the Department of Education.

Under modular learning, materials can be printed or in digitized form. This is the backbone of the Department of Education's distance learning program because access to technology is still an issue for most students. (Department of Education, 2020) In Buluan, Maguindanao Province, ten elementary schools have introduced modular distance learning with printed textbooks. The problems and challenges stem from the fact that educational institutions must ensure the quality of teaching. Some obstacles to progress must be overcome through insufficient technical equipment (Alvarez, 2020) and the failure to consider sociocultural aspects (Karsenti \& Collin, 2012) that could hinder technological adoption.

Teaching is possible but it has issues and concerns due to these abrupt changes in the new educational system. This study aims to determine the issues and concerns of the teachers on the use of Modular Distance Learning Modality in the field of education.

\subsection{Related Studies}

The result of the Department of Education (DepED) National Learner Enrolment and Survey Forms (LESFs) survey, out of the 22.2 million enrollees, 8.8 million or $39.6 \%$ of total respondents preferred modular distance learning for the school year 2020-2021. Further, 3.9 million enrollees or 17.6\% preferred blended learning (which uses a combination of different modalities), 3.8 million or $17.1 \%$ chose online learning, and 1.4 million and 900,000 enrollees selected TV-based and radio-based learning, correspondingly.

In a study by American Community College, Wenner, Burn, and Baer (2011) showed that when teaching mathematics in the context of earth science applications, students do better in correcting math courses. The researchers compared two math types of courses, one using traditional methods., and the use of typically applied mathematics in modular courses. Wenner et al.Found the modular approach in a remedial math course was successful, but that the success of higher levels of student participation and completion depends on the kind of school, courses, quantitative concepts covered, assessment, and teachers teaching methods. The beneficial attendance of the lecturer includes full familiarity with the modules and instructions used to navigate the test site and the learning management system. It also shows that it is very important for teachers to strengthen the module mapping to help students pass the exam after the module. This positive attitude helps students better understand themselves, their academic achievements, and opportunities for success; and motivates them to complete modules. Ultimately, when teachers connect the mathematics they learn with its relevance to real-world problems, students tend to complete the modules more easily. In the modular approach, according to Goldschmidt \& Sejpal (2013), teaching enables the learner to accept greater responsibility for learning and to have control over his/her learning. Goldschmidt \& Sejpal (2013) stresses further, that on the part of the learner, the modular approach demands greater maturity is more suitable for more mature students. In the modular approach, all the capabilities required to perform are closely related. For them, sets of tasks are grouped together. For instance, capabilities required financial management in managing an institution that includes generations of finances, allocation, accounting, and monitoring.

In Addition, Gonzales, (2015) states that modular learning is one of the teaching approaches where the students have to learn everything in the module using their own effort at their own pace. Moreover, He asserted that the method differs from the traditional one wherein the students just listen to learn the concepts presented by the teachers. Further, in order to surpass the difficulties faced by the students in the traditional 
classroom situation, He further suggested that the modular approach may be a good alternative since it is student-centered, self-paced, and requires no note-taking. Also, teaching the English language using a module compared to using a textbook in the traditional methods meant to increase active learning and improve critical thinking, as well as problem-solving skills. It is given the lecturer the opportunity for conducting formative assessments in the classroom.

Cheng and Bakar (2017) also emphasized that standardized textbooks have their own style and organization of their contents, depth of coverage of materials may affect the teaching and learning environment. Thus, according to them, the use of a module presents a more flexible learning environment for both instructors and learners. Modular learning has been in practice for many decades, but at this moment there exists an incredible opportunity to the remarkable learning process with the power of exploding technological innovation. As educators and researchers in a leading online university, educators are poised to offer contributions to the next "Gutenberg" or "printing press" moment in education, which captures the dramatic way human thinking produces a revolutionary movement. The original "Gutenberg moment", which took hundreds of years, created the mass production of books, lower unit cost, democratized ownership of knowledge, and assured consistency and quality in transferring knowledge. Today, the impact of innovation and change is growing exponentially.

The DepEd is providing devices such as computers, tablets, and smart boards to schools that are the Center of Excellence or central schools. Because Technical Elements according to Mean-Chin (2020) is the most substantial issue on distance learning that involves the availability of devices such as mobile phones, computers, laptops, printers, and internet connection for both students and teachers. To Chen \& Huang, 2018; and Hussin (2018) these devices are needed for distance learning education and for embracing the 4.0 trend in education, that promotes the use of the E-instruction system, that enabling learners' achievement and implementing a task-based and performance-based on a specific learning goal.

In the report of the DepEd, over 1 million computer devices were distributed in 44,155 public schools. But, half of these cannot be lent as they are thin clients - computers meant for establishing connections in a farlang area with a server-based computing environment. Also, Phil Vahey and Jim Vanides, (2020) claim that there are still significant hurdles to technology creating more, not less, equitable learning environments. These barriers became apparent during the transition to emergency distance learning during the pandemic. For example, communities need to overcome severe inequalities in access: access to computers, - access to computers, reliable high-speed internet, and the digital literacy and support required to take advantage of learning.

Overdependence on technology can be a major drawback in the distance learning mode of education, especially when the learning takes place in an online environment. Any malfunctioning software or hardware can bring an on-going class to a standstill and interrupt the learning process. Similarly, if a student is not computer and tech-savvy, his learning experience can be dissatisfactory. (Bijeesh, 2020)

\subsection{Statement of the Study}

The study aims to determine the issues and concerns on the use of Modular Learning Modality among teachers in the District of Buluan, Division of Maguindanao I. The study tries to find out the answers to the following questions.

1. To what extent are the issues on Modular Learning Modality in terms of Technical Elements; Teacher's Preparedness; Self-Learning Modules (SLMs); Teacher's Support; and Pupils' Learning?

2. To what extent are the concerns of teachers to Parents/Guardians Support and Material Resources?

\subsubsection{Significance of the Study}

The present paper is significant to study the issues and concerns on the use of Modular Distance Learning Modality among teachers. This study can help educators and planners since it will consider the issues and concerns of the teachers on the use of Modular Distance Learning Modality. The administrators are the foremost personnel who benefited from this study as they will be aware of the issues and concerns of the teachers with regards to the Modular learning delivery modality. This can make them think of what actions can be taken to solve the issues and concerns to reach future targets. This study is also beneficial to the teachers who are affected by these issues on the use of this delivery modality. Through this study, the issues and concerns that they are facing will be settle.

The direct recipients of the output of this study are the students because they are at the center of the educative process. Any improvement in the modular learning system can pave the way for producing better learning to survive and thrive in society. The parents/Guardians also benefit. This study helped them find 
solutions to the concerns arising in the process of the new learning system. It involves proper guidance and proper monitoring of pupils' progress

\section{METHODOLOGY}

The study used the descriptive research design, a technique that helps the researcher to obtain the information or the phenomenon being studied. According to Calderon (2008), as cited by Alberto et al (2011), the descriptive method is also known as statistical research, it describes data and characteristics about the population or phenomenon being studied. The respondents of this study were the 154 teachers from different public elementary schools in Buluan District for the School Year 2020-2021.

This study was conducted in the ten different public elementary schools within the District of Buluan, Division of Maguindanao I. Buluan is strategically located in the southern tip of the Maguindanao Province. It is composed of seven barangays occupying a total land area of 69,950 hectares. It has a substantial share of the famous Buluan Lake. On the South lies the Municipality of Mangudadatu and Pandag on the North all in the Province of Maguindanao. Being accessible through the National Highway, the nearby Municipality of Datu Paglas on the east is only seven (7) Kilometer. On the west is the Municipality of President Quirino, Sultan Kudarat Province which was once part of Buluan. The presence of the National Highway makes the locality accessible and a drop-off point when traveling to other cities in Mindanao, such as Davao, Cagayan, Cotabato, Tacurong, Marbel, and General Santos to name a few.

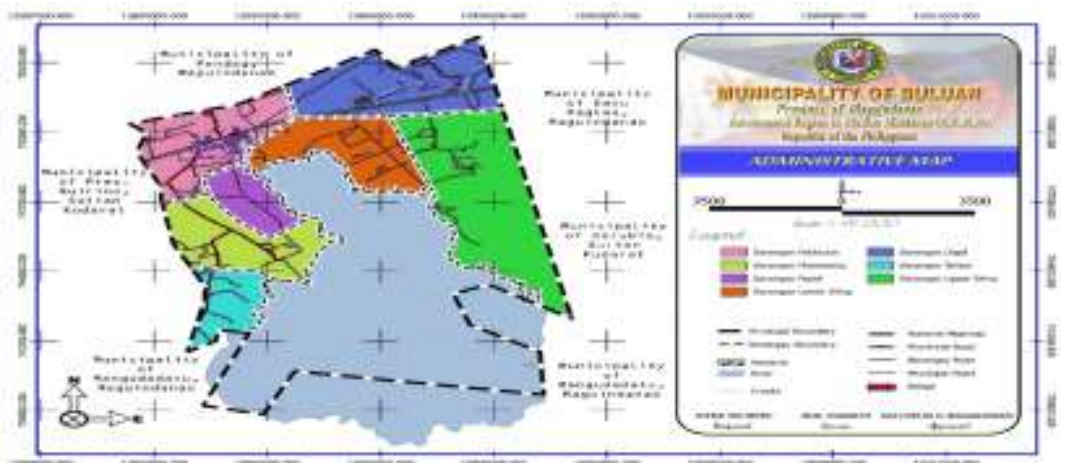

Fig. 1. Map of the Municipality of Buluan in the Maguindanao Province, its location, and its nearby places.

\section{RESULTS}

\subsection{Results on Teachers Issues}

\subsubsection{Teachers Issues on Technical Elements}

Table 1 presents the extent of the issues on technical elements. The highest weighted mean is 3.84 and is interpreted as "Highly Evident" exemplified in item number 10. This means that printers and photocopier machines are available and functional in school for the reproduction of Self-Learning Modules. The lowest weighted mean value is 1.83 and is interpreted as "Less Evident" exemplified in item number 2. This means that there are no laptops or computers provided by the Department of Education for every teacher in this time of new normal education. The overall weighted mean value is 2.91, having an interpretation of "Evident". This implies that the teachers have their own personal laptops, computers, cell phones and they have an adequate technical capacity in adopting and using these technologies. According to Education Undersecretary Nepomuceno Malaluan, (2020), Out of 700,000 teachers nationwide who answered the recent survey, $87 \%$ have laptops or computers at home and $13 \%$ have none. Among those who have gadgets, only $41 \%$ have an internet signal in their area but no connection of their own. According to the Department of Education (DepEd), Undersecretary for operations Jesus Lorenzo Mateo (2020), providing teachers with their own laptops will already cost P23 billion, according to previous estimates by the department. The department will also have to expand the technical capacity of teachers to adopt new technology, such as by providing them with equipment and training to adapt to the new learning strategies. (Jesus Lorenzo Mateo, 2020) 
Table 1. Teachers Issues on Technical Elements

\begin{tabular}{|c|c|c|}
\hline Indicators & Mean & Interpretation \\
\hline $\begin{array}{l}\text { 1. The School is technologically prepared for modular } \\
\text { learning modality }\end{array}$ & 3.02 & Evident \\
\hline $\begin{array}{l}\text { 2. There are laptops or computers available for every } \\
\text { teacher. }\end{array}$ & 1.83 & Less Evident \\
\hline $\begin{array}{l}\text { 3. Modules are available in Ministry of Basic, Higher and } \\
\text { Technical Education links and ready to download. }\end{array}$ & 3.23 & Evident \\
\hline $\begin{array}{l}\text { 4. Using of smart phones, laptops, computers for } \\
\text { downloading of modules is easy for teachers. }\end{array}$ & 3.12 & Evident \\
\hline $\begin{array}{l}\text { 5. Teachers have a reasonable level of competence with } \\
\text { computers. }\end{array}$ & 3.66 & Highly Evident \\
\hline $\begin{array}{l}\text { 6. The geographical location of school is considered as } \\
\text { hotspot to access strong internet connection. }\end{array}$ & 2.07 & Less Evident \\
\hline 7. Internet access is also available all the time in school. & 1.87 & Less Evident \\
\hline 8. Electricity is also available in all classrooms. & 3.38 & Evident \\
\hline $\begin{array}{l}\text { 9. The school provides contact tracing record for parents } \\
\text { entering in school. }\end{array}$ & 3.09 & Evident \\
\hline $\begin{array}{l}\text { 10. Printers and photocopier machines are available in } \\
\text { school. }\end{array}$ & 3.84 & Highly Evident \\
\hline Mean Average & 2.91 & Evident \\
\hline
\end{tabular}

$\begin{array}{ll}\text { 3.46-4.00 } & \text { Highly Evident } \\ 2.46-3.45 & \text { Evident } \\ 1.46-2.45 & \text { Less Evident } \\ 1.00-1.45 & \text { Least Evident }\end{array}$

\subsubsection{Teachers Issues on Teacher's Preparedness}

Table 2 shows the extent of the issues on the use of teacher's preparedness. The highest weighted mean is 3.71 and is interpreted as "Highly Evident" exemplified in item number 5 . It tells that teachers had proper training in the use of technology needed for learning dissemination. Item number 7 was rated lowest weighted mean is 3.07 which is interpreted as "Evident". This shows that the schools have provided enough supplementary materials for modular learning.

The overall rating is 3.30 having an interpretation of "Evident". This technically implies that teachers are trained and well-oriented to be prepared to perform their tasks and functions on modular distance learning education in times of pandemic.

According to Undersecretary Diosdado San Antonio (2020), states that 300,000 teachers have so far been trained and ready to teach under distance learning modality. DepEd aimed to finish preparing teachers before the school year 2020-2021 starts. "Aside from the training, there are also local initiatives from the division offices, regional offices where the teachers are also being given training activities," 
IJASOS- International E-Journal of Advances in Social Sciences, Vol. VII, Issue 20, August 2021

Table 2. Teachers Issues on Teacher's Preparedness

\begin{tabular}{|c|c|c|}
\hline Indicators & Mean & Interpretation \\
\hline $\begin{array}{l}\text { 1. Teachers were prepared to conduct distance Learning } \\
\text { Education in times of COVID-19. }\end{array}$ & 3.56 & Highly Evident \\
\hline $\begin{array}{l}\text { 2. Teachers were prepared to use printed modules as a } \\
\text { tool for learning at home. }\end{array}$ & 3.29 & Evident \\
\hline $\begin{array}{l}\text { 3. Teachers are monitoring and tacking the learners' } \\
\text { accomplishment of the task provided in the SLMs }\end{array}$ & 3.14 & Evident \\
\hline $\begin{array}{l}\text { 4. Teachers had capacity building on distance learning } \\
\text { education management for teachers. }\end{array}$ & 3.12 & Evident \\
\hline $\begin{array}{l}\text { 5. Teachers had a proper training in the use of technology } \\
\text { needed for learning dissemination. }\end{array}$ & 3.71 & Highly Evident \\
\hline $\begin{array}{l}\text { 6. The school has provided the regulation and policies on } \\
\text { the use modular learning. }\end{array}$ & 3.13 & Evident \\
\hline $\begin{array}{l}\text { 7. The school has provided supplementary materials for } \\
\text { modular learning. }\end{array}$ & 3.07 & Evident \\
\hline 8. Teachers are well-oriented in delivering modules. & 3.17 & Evident \\
\hline $\begin{array}{l}\text { 9. The school has designated skeletal workforce for the } \\
\text { COVID-19 pandemic. }\end{array}$ & 3.5 & Highly Evident \\
\hline $\begin{array}{l}\text { 10. Virtual communication is done for more information from } \\
\text { the Ministry of Basic, Higher and Technical Education/ } \\
\text { Division Office. }\end{array}$ & 3.21 & Evident \\
\hline Mean Average & 3.30 & Evident \\
\hline
\end{tabular}
3.46-4.00 Highly Evident
2.46-3.45 Evident
1.46-2.45 Less Evident
1.00-1.45 Least Evident

\subsubsection{Teachers Issues on Self-Learning Modules}

As presented in table 3, the extent of the issues on the use of Self-Learning Modules. The highest weighted mean is 3.95 and is interpreted as "Highly Evident" exemplified in item number 7. This implies that the key concepts in all printed modules are not limited and it is deepened. The lowest weighted mean is 2.02 and is interpreted as "Less Evident" which means that there are excess copies of Self-Learning Modules because not all parents are interested to get a copy in school.

The overall rating is 3.02 having an interpretation of "Evident". This implies that there are no problems in the reproduction and releasing of Self-Learning Modules. The department of education has prepared all necessary budgets for the reproduction of SLMs. Links for SLMs are available anytime when downloading.

According to DepEd (2020), partial results of the Learner Enrolment and Survey Form (LESF) distributed during the enrolment period showed that more than 8.8 million parents chose modular learning as their preferred distance learning modality as an alternative to in-person classes this school year 2020-2021. 
"The SLMs and the other alternative learning delivery modalities are in place to address the needs, situations, and resources of each and every learner and will cover all the bases in ensuring that basic education will be accessible amid the present crisis posed by COVID-19," DepEd Secretary Leonor Briones, (2020). According to Education Undersecretary and Spokesperson Annalyn Sevilla (2020), "DepEd has funds to reproduce learning modules. "We have downloaded funds down to division offices, totaling about P9 billion already. The guidelines on the use of funds have also been released to regional offices as well as to school's division offices."

Table 3. Teachers Issues on Self-Learning Modules

\begin{tabular}{|c|c|c|}
\hline Indicators & Mean & Interpretation \\
\hline 1. All printed modules are available to distribute. & 3.70 & Highly Evident \\
\hline $\begin{array}{l}\text { 2. There is a rapid reproduction of SLMs because school } \\
\text { has enough printing equipment. }\end{array}$ & 3.11 & Evident \\
\hline $\begin{array}{l}\text { 3. Releasing of SLMs are on time because of } \\
\text { enough school supplies. }\end{array}$ & 3.14 & Evident \\
\hline $\begin{array}{l}\text { 4. Reproduction cost is not a big problem as schools has } \\
\text { enough funds. }\end{array}$ & 2.33 & Less Evident \\
\hline $\begin{array}{l}\text { 5. There's s no excess copy of SLMs because all parents } \\
\text { we're able to receive it. }\end{array}$ & 2.02 & Less Evident \\
\hline $\begin{array}{l}\text { 6. Self-Learning Modules has no } \\
\text { erroneous contents. }\end{array}$ & 2.62 & Evident \\
\hline $\begin{array}{l}\text { 7. Key concepts on SLMs are not limited and it is } \\
\text { deepened. }\end{array}$ & 3.95 & Less Evident \\
\hline $\begin{array}{l}\text { 8. The language use and degree of difficulties to different } \\
\text { type of learners were considered. }\end{array}$ & 3.14 & Evident \\
\hline $\begin{array}{l}\text { 9. The activities and exercises are suited to the multiple } \\
\text { abilities of learners. }\end{array}$ & 3.12 & Evident \\
\hline $\begin{array}{l}\text { 10. Assessment designs in the SLMs are sensitive to the } \\
\text { abilities, interest, developmental preparedness and } \\
\text { available resources at home. }\end{array}$ & 3.12 & Evident \\
\hline Mean Average & 3.02 & Evident \\
\hline
\end{tabular}

$\begin{array}{ll}\text { 3.46-4.00 } & \text { Highly Evident } \\ 2.46-3.45 & \text { Evident } \\ 1.46-2.45 & \text { Less Evident } \\ 1.00-1.45 & \text { Least Evident }\end{array}$

\subsubsection{Teachers Issues on Teacher's Support}

Table 4 shows the extent of the issues on teacher support. The highest weighted mean is 3.13 and is interpreted as "Evident" exemplified in item number 4. This means that teachers have established a network of communication among stakeholders such as parents for support at home. The lowest weighted mean is 2.15 and is interpreted as "Less Evident" exemplified in items number 8 and 10. It tells that beating the deadlines and requirements set by the school administrators are not easy and managing stress caused by the community quarantine at home and rush reproduction of SLMs is difficult. 
The overall weighted mean is 2.65 having the interpretation of "Evident" says that teachers have adequate communication with the parents to support a child's learning at home. They also have enough training and skill development necessary to effectively and efficiently do their job. According to Undersecretary for Curriculum and Instruction Diosdado San Antonio (2020), another thing that most likely influences the effectiveness of the learning activities for distance learning delivery modality is the presence of the intense communication mechanism between the teachers and the parents or guardians and learners. Because constant communication, doubts, confusions and uncertainties, and even the difficult activities or problems will be addressed effectively that have been assigned to be undertaken and solved by learners".

Table 4. Teachers Issues on Teacher's Support

\begin{tabular}{|c|c|c|}
\hline Indicators & Mean & Interpretation \\
\hline $\begin{array}{l}\text { 1. Teachers can easily finish printing, sorting and organizing } \\
\text { SLMs for the succeeding weeks. }\end{array}$ & 3.10 & Evident \\
\hline 2. Teachers are safe to do home visitation when needed. & 2.88 & Evident \\
\hline $\begin{array}{l}\text { 3. Teachers are not facing dangerous path everyday within } \\
\text { modular learning set up. }\end{array}$ & 2.27 & Less Evident \\
\hline $\begin{array}{l}\text { 4. Establishing a network of communication among } \\
\text { stakeholders such as parents for support at home is } \\
\text { easy. }\end{array}$ & 3.13 & Evident \\
\hline $\begin{array}{l}\text { 5. Checking and evaluating children's output from modules } \\
\text { exercises is not a big problem. }\end{array}$ & 3.12 & Evident \\
\hline 6. Monitoring children's learning is easy. & 2.60 & Evident \\
\hline 7. Giving instructions to the parents is easeful. & 2.16 & Less Evident \\
\hline $\begin{array}{l}\text { 8. Managing stress caused by community quarantine at } \\
\text { home and rush reproduction of SLMs is simple. }\end{array}$ & 2.15 & Less Evident \\
\hline $\begin{array}{l}\text { 9. Teachers had a virtual trainings and skills development to } \\
\text { face the new learning modality. }\end{array}$ & 2.95 & Evident \\
\hline $\begin{array}{l}\text { 10. Beating the deadlines and requirements set by the } \\
\text { school administrators are so easy. }\end{array}$ & 2.15 & Less Evident \\
\hline Mean Average & 2.65 & Evident \\
\hline
\end{tabular}
3.46-4.00 Highly Evident
2.46-3.45 Evident
1.46-2.45 Less Evident
1.00-1.45 Least Evident

\subsubsection{Teachers Issues on Pupils' Learning}

Table 5 presents the extent of the issues on pupils' learning. The highest weighted mean is 2.78 and is interpreted as "Evident" exemplified in item number 5. This tells that learners are updated in feed backing due to communication. The lowest weighted mean is 1.90 and is interpreted as "Less Evident" exemplified in item number 10. This means that the Learners are not capable to learn independently from the modules because of no face-to-face instruction. The overall weighted mean value is 2.28 having an interpretation of "Less Evident" shows that learners cannot totally focus on learning due to the absence of face-to-face instruction and most of the parents especially in remote areas have a lack of capacity to explain the module provided for their children. 
According to Michael Alba the president of Far Eastern University, remote learning will basically be homeschooling and this is where the problem lies. He also added that teachers are trained to develop rapport with their learners and parents may not have the skill or patience to fill that role. Alba further Said, that parents may have a different relationship with their children. So, pupils will miss their teachers. Our students tend to be fragile. With a hint of a weather disturbance, they clamor for the suspension of classes. What should be included in the intended learning outcomes of the curriculum is agency - the inclination and propensity to take purposeful initiative, which is the opposite of helplessness. Alba (2020) opined, if students have agency, they will strive to meet their learning goals, rather than being "passive recipients of instructions."

Table 5. Teachers Issues on Pupils' Learning

\begin{tabular}{|c|c|c|}
\hline Indicators & Mean & Interpretation \\
\hline $\begin{array}{l}\text { 1. Learners can focus on learning even there's a lot of } \\
\text { temptations like gadgets. }\end{array}$ & 2.08 & Less Evident \\
\hline $\begin{array}{l}\text { 2. Learners can concentrate on learning even there's a lot } \\
\text { of distraction like household chores. }\end{array}$ & 2.01 & Less Evident \\
\hline $\begin{array}{l}\text { 3. High self-motivation because of communication to the } \\
\text { teachers. }\end{array}$ & 2.73 & Evident \\
\hline $\begin{array}{l}\text { 4. Learners develop sense of responsibility in accomplishing } \\
\text { the task provided in the module. }\end{array}$ & 2.16 & Less Evident \\
\hline 5. Updates feedbacking due to communication & 2.78 & Evident \\
\hline $\begin{array}{l}\text { 6. Learners pay attention to their parents since they always } \\
\text { prefer learning. }\end{array}$ & 2.11 & Less Evident \\
\hline $\begin{array}{l}\text { 7. Learners can learn at home because they are with their } \\
\text { parents who are assisting them. }\end{array}$ & 2.32 & Evident \\
\hline $\begin{array}{l}\text { 8. Submission deadlines for SLMs are not a pressure on the } \\
\text { learners. }\end{array}$ & 2.70 & Evident \\
\hline 9. Ensuring learners to learn from the modules is easy. & 1.99 & Less Evident \\
\hline $\begin{array}{l}\text { 10. Learners are capable to learn independently from the } \\
\text { modules. }\end{array}$ & 1.90 & Less Evident \\
\hline Mean Average & 2.28 & Less Evident \\
\hline
\end{tabular}

$\begin{array}{ll}\text { 3.46-4.00 } & \text { Highly Evident } \\ 2.46-3.45 & \text { Evident } \\ 1.46-2.45 & \text { Less Evident } \\ 1.00-1.45 & \text { Least Evident }\end{array}$

\subsection{Result on Teachers Concerns}

\subsubsection{Teachers Concerns on Parents/Guardians Supports}

Table 6 shows the extent of the concerns on the use of modular learning modality in terms of parents/guardian support. The highest weighted mean is 3.13 and is interpreted as "Evident" exemplified in item number 9. This means that parents can easily communicate with the teachers if there are some unclarified instructions. The lowest weighted mean is 2.18 and is interpreted as "Less Evident" which shows that not all parents/guardians have the capacity to facilitate the modular learning sessions for their children. The overall weighted mean is 2.73 which falls under the interpretation of "Evident". This means that 
parents/guardian can support their children in the new learning modality but some of them are hampered because of incapability of facilitating and explaining the modules provided for their children.

Since education is no longer held in school, parents serve as partners of teachers in education. According to Dr. Estela Cariño (2020) director of the Department of Education's office in the Cagayan Valley region said that one of the major challenges experienced by the teacher, is the distance of the houses of learners and the kind of road that have to pass through, some have to cross rivers. There are learners who do not have parents that could help them in studying their lessons at home while there are parents who answer the SLMs for their children (Cariño, 2020)

Table 6. Teachers Concerns of Parents/Guardians Supports

\begin{tabular}{|c|c|c|}
\hline Indicators & Mean & Interpretation \\
\hline 1. Parents are able to receive and return the SLMs on time. & 2.18 & Less Evident \\
\hline $\begin{array}{l}\text { 2. Parents are able to encourage their children to learn at } \\
\text { home. }\end{array}$ & 3.10 & Evident \\
\hline $\begin{array}{l}\text { 3. Parents have the capacity to facilitate the modular } \\
\text { learning sessions for their children }\end{array}$ & 2.14 & Less Evident \\
\hline $\begin{array}{l}\text { 4. Parents and other members of the family are helping in } \\
\text { answering the SLMs. }\end{array}$ & 3.10 & Evident \\
\hline $\begin{array}{l}\text { 5. Some parents have more children to mentor but still able } \\
\text { to assist them. }\end{array}$ & 2.64 & Evident \\
\hline 6. Provides materials for the project of their children. & 2.66 & Evident \\
\hline 7. Help children to make projects at home. & 2.81 & Evident \\
\hline 8. Guide their children in doing activities and experiments. & 2.71 & Evident \\
\hline $\begin{array}{l}\text { 9. Parents can easily communicate to the teachers if there } \\
\text { are some unclarified instructions. }\end{array}$ & 3.13 & Evident \\
\hline $\begin{array}{l}\text { 10. Parents can manage to help their kids learn while looking } \\
\text { for ways to earn. }\end{array}$ & 2.86 & Evident \\
\hline Mean Average & 2.73 & Evident \\
\hline
\end{tabular}
3.46-4.00 Highly Evident
2.46-3.45 Evident
1.46-2.45 Less Evident
1.00-1.46 Least Evident

\subsubsection{Teachers Concerns on Material Resources}

Table 7 presents the extent of the concerns on material resources. The highest weighted mean is 3.56 which is interpreted as "Highly Evident". This shows that there is adequate financial support from the ministry of Basic, Higher, and Technical Education. The lowest weighted mean is 1.99 and is interpreted as "Less Evident" tells that there are no donations from the different organizations for the reproduction of SelfLearning Modules. The overall weighted mean value is 2.94 and interpreted as "Evident". This implies that the schools have given sufficient funds and resources and it is utilized in its proper allocation.

DepEd Order No.18, s.2020 establishes the guidelines that will enable the provision of learning resources in the implementation of the BE-LCP. It also provides the guidelines on the release, utilization, and liquidation of support funds for the printing and delivery of self-learning modules and other learning resources. Annalyn Sevilla (2020) the Education Undersecretary and Spokesperson assures that in the school year 2020-2021, 
there would be no sharing of Self-Learning Modules (SLMs), vowing a ratio of 1:1. She further asserted that this 2020, there will be a 1:1 ratio SLMs. Sevilla (2020) said, noting that DepEd already realigned, reprioritized, and utilized the Special Education Fund for the new requirements of off-school learning after Local Government Units (LGUs) gave their support.

Table 7. Teachers Concerns on Material Resources

\begin{tabular}{lccc}
\hline \multicolumn{1}{c}{ Indicators } & Mean & Interpretation \\
\hline $\begin{array}{l}\text { 1. The school has enough budget for reproduction. } \\
\begin{array}{l}\text { 2. Overwhelming printing causal equipment is not a big } \\
\text { problem because school has a lot of resources. }\end{array}\end{array}$ & 3.05 & Highly Evident \\
\hline $\begin{array}{l}\text { 3. The ability to generate more resources to supply the } \\
\text { printing materials in school is easy. }\end{array}$ & 2.89 & Evident \\
\hline $\begin{array}{l}\text { 4. Schools don't need to solicit private donations just to } \\
\text { jumpstart the reproduction of modules. }\end{array}$ & 3.07 & Evident \\
\hline
\end{tabular}

5. There is an adequate financial support from the Ministry of $3.56 \quad$ Highly Evident Basic, Higher and Technical Education.

6. There is a balance in expenditures resulting to sufficient resources and finances.

$2.99 \quad$ Evident

7. There are more donations from the different Private

1.99 Less Evident organization.

8. Local Government Unit supports the school for the SLMs

3.18

Evident reproduction.

9. Local community and government stakeholders supported $2.95 \quad$ Evident schools by providing Technology and multi-media like desktops, laptops, printers and other electronic devices such as tablets, e-books and multimedia board.

10. Financial assistance for the reproduction of SLMs is fully $3.01 \quad$ Evident utilized.

\begin{tabular}{lll}
\hline Mean Average & 2.94 & Evident \\
\hline
\end{tabular}
3.46-4.00 Highly Evident
2.46-3.45 Evident
1.46-2.45 Less Evident
1.00-1.45 Least Evident

\subsection{Conclusions}

Teachers and the school where they are teaching were prepared in terms of technical elements. Teachers also expressed their preparedness to perform their tasks and functions related to the teaching and learning process on the new normal education. The Self-Learning Modules (SLMs) are reliable and there is a smooth reproduction and releasing of them. Teachers have adequate training and skill development webinars necessary to effectively do their work. However, there is an issue when it comes to pupils learning. Learners cannot totally focus on learning due to the absence of face-to-face instruction. 
Parents/guardians can encourage and support their children to face the new learning modality. But, some of them felt hampered due to a lack of capacity to facilitate and explain in the modular learning session. The challenges parents are facing in their ability to assume responsibility as teachers for their children. The parents' educational background and socioeconomic status play an important role in their children learn remotely and to what extent they can adapt to modular learning. Furthermore, the schools have sufficient financial support and material resources and it is properly utilized to sustain the massive reproduction of Self-Learning Modules (SLMs).

\subsection{Recommendations}

Based on the findings of the study, the following recommendations are strongly forwarded:

1. The Department of Education shall allocate an additional budget for facilities and equipment needed for modular distance learning modalities.

2. Teachers should formulate a suitable plan and continue to implement sufficient strategies to meet the demand for new normal education.

3. Teachers and parents must have a collaborative effort in keeping track of learner's everyday activities and give strategic intervention to monitor learners' progress.

4. Stakeholders may work with the teachers in addressing the issues and concerns they face as they shift to the new normal teaching practices.

5. Providing necessary resources and relevant training and skills development webinars among teachers shall be maintained to successfully deliver quality education.

6. Parents'/Guardians' support to educate children first at home should be encouraged so that they will be guided properly. They should follow up on the assessment result and the learning performance of learners at home.

\section{ACKNOWLEDGEMENT}

This paper has been completed with the help of the teachers of Maguindanao I Schools Division in gathering the data. We would like also to thank the referees who anonymously checked this paper and for their constructive comments and useful suggestions.

\section{REFERENCE LIST}

Alvarez, A. Jr. (2020). The phenomenon of learning at a distance through emergency remote teaching amidst the pandemic crisis. Asian Journal of Distance Education, 15(1), 144-153. https://doi.org/10.5281/zenodo.3881529

Bernardo, J. (2020). Modular Learning most preferred parents: DepEd. ABS-CBN News. https://news.abs cbn.com/news/07/30/20/modular-learning-most-preferred-by-parentsdeped

Bozkurt, A. \& Sharma, R. C. (2020). Emergency remote teaching in a time of global crisis due to Corona Virus pandemic. Asian Journal of Distance Education, 15(1). https://doi.org/10.5281/zenodo.3778083

Bonz Magsambol (2020) DepEd: 40\% of public school teachers trained for distance learning https://www.rappler.com/nation/senators-question-philippines-distance-learning-readiness-june-2020

Chen, J. F., \& Huang, H. F. (2018). An empirical study on the factors influencing the web-based teaching effect. Eurasia Journal of Mathematics, Science and Technology Education, 14(5), 1635-1643. https://doi.org/10.29333/EJMSTE/85035

Cheng, M B Bakar (2017) The Impact of Using Modules in the Teaching and Learning of English in Malaysian Polytechnics: An Analysis of the Views and Perceptions of English Language Teaching. Jabatan Pengajian Am

Ciriako, C. (2020) The impossible is possible: Covid shut down schools, but learning goes on https://businessmirror.com.ph/2020/10/08/the-impossible-is-possible-covid-shut-down-schools-butlearning-goes-on/

DepEd Order No. 12 s, 2020 Adoption of the Basic Education Learning Continuity Plan for School Year 2020-2021 in Light of the COVID-19 Public Health Emergency (June 19, 2020) 
DepEd Order No. 18 s, 2020 Policy Guidelines for the Revision of Learning Resources in the Implementation of Basic Education Learning Continuity Plan (July, 2020)

Hussin, A. A. (2018). Education 4.0 Made Simple: Ideas For Teaching. International Journal of Education \& Literacy Studies. http://dx.doi.org/10.7575/aiac.ijels.v.6n.3p.92

Llego, MA. (n.d). DepEd Learning Delivery Modalities for School Year 20202021.TeacherPh.https://www.teacherph.com/deped-learning-delivery-modalities/

Manlangit,P., Paglumotan,A.M. \& Sapera,S. (2020). 'Tagapagdaloy': How Filipino parents can help ensure successful modular distance learning. FlipScience - Top Philippine Science News and Features for the Inquisitive Filipino. https://www.flipscience.ph/news/features-news/tagapagdaloymodular-distancelearning/

Mateo, J. (2020) DepEd seeks more fund for Blended Learning https://www.philstar.com/headlines/2020/06/04/2018586/deped-seeks-more-funds-blended-learning

Malipot, Merlina (2020) P 9 Billion downloaded for the reproduction of Self-Learning Modules (SLMs) https://mb.com.ph/2020/08/05/p9-b-downloaded-for-reproduction-of-self-learning-modules/

Mean-Chin (2020) Students' New Normal: Modular Distance Learning https://www.uniquephilippines.com/students-new-normal-modular-distance-learning/

Phil Vahey, and Jim Vanides,(November 2020) Technology's role in the next new normal in education https://medium.com/dish/technologys-role-in-the-next-new-normal-in-education-2c8ba11b749

Pimentel-Tibon, J. (2020). The New Normal in basic education https://www.bworldonline.com/the-newnormal in-basic-education/

Quinones, M. T. (2020). DepEd clarifies blended, distance learning modalities for SY 2020- 2021. Philippine Information Agency. https://pia.gov.ph/news/articles/1046619

Sarao, Z. (2020) DepEd Maximize use of Special Education Fund for Distance Learning. https://newsinfo.inquirer.net/1368012/deped-to-maximize-use-of-special-education-fund-for-distancelearning

Sejpal, K. (2013). Modular method of teaching. International Journal for Research in Education, volume 2, p. $169-171$

The Manila Times Newsletter (2020) Problems with distance learning system must be thoroughly Investigated https://www.manilatimes.net/2020/10/21/opinion/editorial/problems-with-distancelearning-system-must-be-thoroughly-investigated/783310/

Wenner, J. M., Burn, H. E., \& Baer, E. M. (2011). The Math You Need, when You Need It: Online Modules that Remediate Mathematical Skills in Introductory Geoscience Courses. Journal of College Science Teaching, 41(1), 16- 24. 